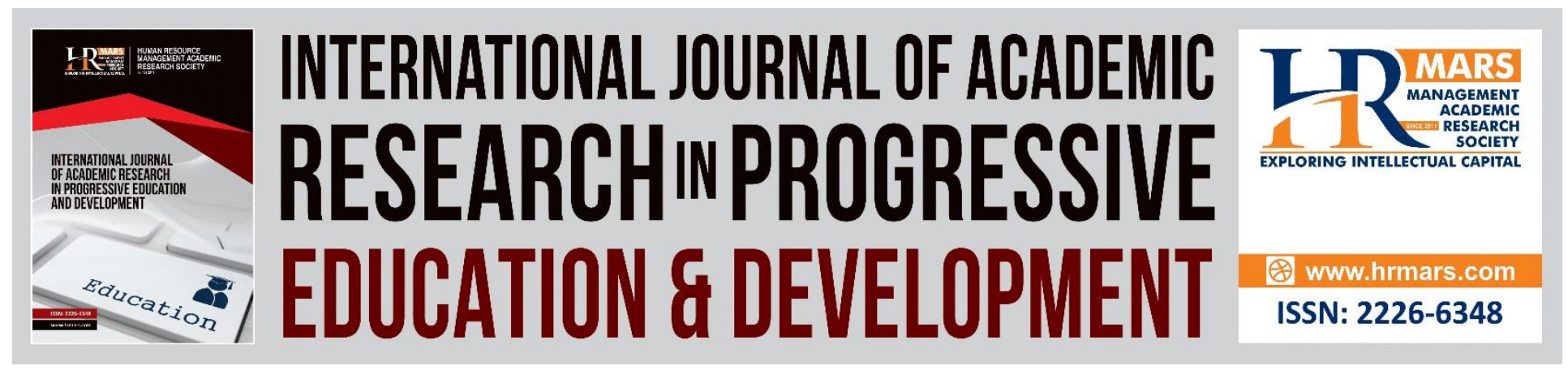

\title{
The Development of Basic Electrical Circuit Kit as Learning Aids for Design and Technology Subject
}

Zaliza Hanapi, Tang Jing Rui, Ridzwan Che'Rus, Nur Fazlinda Dahalan, Muhamad Shazielan Sharif, Ummu Sakinah Subari, Rafaeizah Mohd Zulkifli

To Link this Article: http://dx.doi.org/10.6007/IJARPED/v10-i2/9918

DOI:10.6007/IJARPED/v10-i2/9918

Received: 12 February 2021, Revised: 10 March 2021, Accepted: 27 March 2021

Published Online: 24 April 2021

In-Text Citation: (Hanapi et al., 2021)

To Cite this Article: Hanapi, Z., Rui, T. J., Che'Rus, R., Dahalan, N. F., Sharif, M. S., Subari, U. S., \& Zulkifli, R. M. (2021). The Development of Basic Electrical Circuit Kit as Learning Aids for Design and Technology Subject. International Journal of Academic Research in Progressive Education and Development, 10(2), 410-415.

Copyright: (C) 2021 The Author(s)

Published by Human Resource Management Academic Research Society (www.hrmars.com)

This article is published under the Creative Commons Attribution (CC BY 4.0) license. Anyone may reproduce, distribute, translate and create derivative works of this article (for both commercial and non-commercial purposes), subject to full attribution to the original publication and authors. The full terms of this license may be seen

at: http://creativecommons.org/licences/by/4.0/legalcode

Vol. 10(2) 2021, Pg. 410 - 415

http://hrmars.com/index.php/pages/detail/IJARPED

JOURNAL HOMEPAGE

Full Terms \& Conditions of access and use can be found at http://hrmars.com/index.php/pages/detail/publication-ethics 


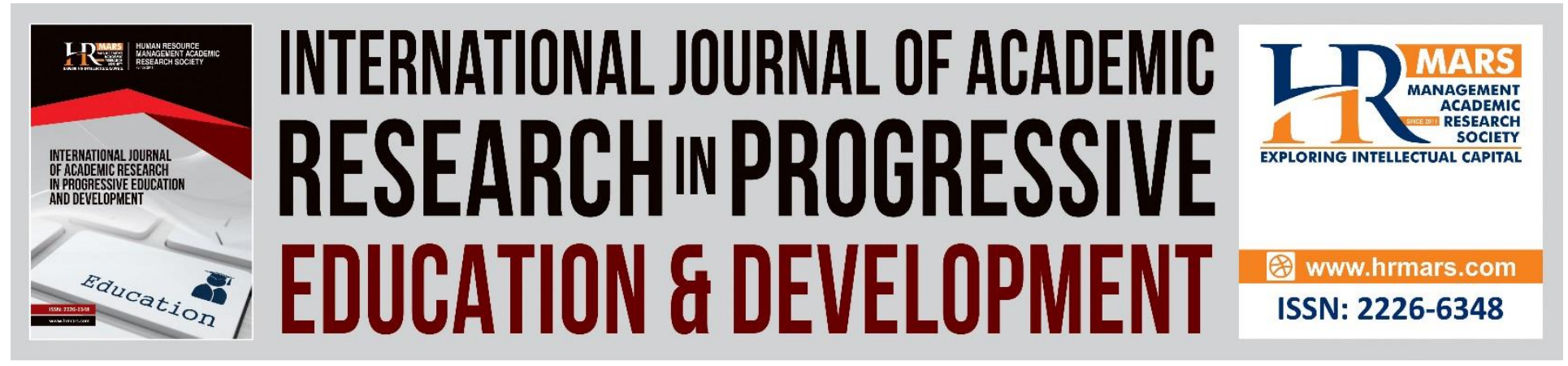

\title{
The Development of Basic Electrical Circuit Kit as Learning Aids for Design and Technology Subject
}

\section{Zaliza Hanapi, Tang Jing Rui, Ridzwan Che'Rus, Nur Fazlinda Dahalan, Muhamad Shazielan Sharif, Ummu Sakinah Subari, Rafaeizah Mohd Zulkifli}

Universiti Pendidikan Sultan Idris, Tg. Malim, Perak. Malaysia

\begin{abstract}
Teaching aids are very important in the teaching and facilitating process as it can help to enhance and improve the students' understanding to a much deeper and realistic level. The purpose of this study is to develop a basic electrical circuit kit as one of the teaching aids, which aimed at helping to enhance and improve the understanding of students and teachers when teaching and facilitating process is implemented especially for electrical subtopics under the Design and Technology subjects. The researcher had opted to use the Waterfall model as the basis of product development in which comprises several steps such as planning, analysis, design, and implementation. The implication of this research development is that it can help to produce teaching aids which further enhance the student understanding thus improved the student achievement in relation to basic electrical circuits.
\end{abstract}

Keywords: Teaching Aids, Electrical, Circuit Kit, Design and Technology

\section{Introduction}

Teaching aids are an integral component in the process of teaching and facilitating. The use of teaching aids can help to disseminate information regarding the subject that is being taught more clearly and systematically to the student. With the use of teaching aids, its' allowed the teacher to explain matters and concepts of the learning content more accurately compared to only depend solely on verbal explanations. A teacher needs to have an early preparation along with the knowledge to manage the material needed for the process of teaching and facilitating. The electrical subtopic under the Design and Technology subject are one of the difficult subjects to be understood, especially if the process teaching and facilitating is ineffective. The lack of interest in the topic among students is due to their weakness itself to make assumptions and visualization illustrations for topics involving the use of skills and body parts. The failure to explain the learning contents with a clear, concise, and precise explanation causes the student to feel bored, lackluster and think that the subject is difficult and uninteresting (Elyani \& Minarnie, 2013). 
Vol. 10, No. 2, 2021, E-ISSN: 2226-6348 @ 2021 HRMARS

Hence, the teacher plays an important role in nurturing and attracting the attention of the students to study the Design and Technology subject. This study is conducted with the purpose to

- Develop a basic electric circuit kit as one of the teaching aids for the Design and Technology subject.

The idea of producing a basic electrical circuit kit is triggered when schools have no real electric circuit models that can be used by students during the process of teaching and facilitating. The product development as teaching aids can help to overcome the problem faced during the process of teaching and facilitating, especially the problem faced in the electrical subject and at the same time can help to improve the success of learning the subject. It helps in facilitating the student to identify the types of circuits and types of damaged that can happen to the circuit. In addition, the teaching aids are developed with the form and functions that can help to attract the student towards the topic of the electrical technology that are being taught.

\section{Literature Review}

The use of teaching aids during the teaching and facilitating process is one of the most effective ways to create a conducive learning environment. This is because the student will be attracted to the teaching aids if they are advanced, have quality, and is highly developed. This method can be applied in all subjects, especially teachers who teach the Design and Technology subject as this subject is one of the subjects that require practicality to further enhance the students' understanding. Technical subjects such as the Design and Technology subject required teaching in the form of an instructional exercise and practice in the workshop.

This will make them easily feel bored if the process of teaching and facilitating are conducted by using theory only. The use of the teaching aids will help to attract the attention of the student, influencing their way of thinking, and at the same time able to give them a clear picture before they went to perform the practical work. With the teaching aids, the student can better understand the content of the lesson through an easy and accurate explanation compared to the oral description. Based on the study by Abdul Samad et. al (2016), it stated that the existence of the teaching kit, the teaching and facilitating process will become easier as students can detect faults in the wiring connection via the given response and it encourages the student to be more confident when they successfully performing circuit that connect and function properly. Additionally, the study by Ramzi (2014) to examine the use of the basic electronic circuit kit among Community College students had discovered that with the creation of the basic electronic circuit kit, $100 \%$ of the student are showing their interest and able to understand basic electronic and electrical circuit in-depth before they practically conducted it in the classroom. The teaching aids can also help students in looking at the real situation involving the electrical and electronics circuits. It also can act as an early exposure to the student before their practical started.

\section{Research Methodology}

This research is a product development research that uses a Waterfall model. The reason for the researchers to use this model is because the phase that occur in the development of this project 
Vol. 10, No. 2, 2021, E-ISSN: $2226-6348$ @ 2021 HRMARS

are in sequence. There are four phases based on the Waterfall model which is the planning phase, requirement analysis phase, design phase, and product implementation phase.

\section{Findings}

The development of basic electrical circuit kit as teaching aids for the Design and Technology subject.

The development of basic electric circuit kit for the Design and Technology subject is based on a Waterfall model which comprises four phases:

\section{a) Planning phase}

This phase is the first phase and the most important phase in the product development of basic electric circuit kit as teaching aids. This phase aims to ensure the product that will be created can address the problem faced by students during the learning process as well as being a very useful teaching aid for teachers to demonstrate or to be used in the practical work when involving the electrical circuit.

\section{b) Requirement analysis phase}

Once the product planning phase is completed, the requirement analysis phase will begin. The results obtained from the product planning phase will be used as a source in this phase. The first step to be taken is to look at the product requirements that will be produced. This step is to know the functions that can be performed by basic electric circuit kit as the teaching aids. Through the development of the basic electronic circuit kit, it is found that it has a lot of benefits as it has the potential to be used as the teaching aids in school and make it easier for the teacher to conduct teaching and learning process when they used it during the practical or theoretical class. The built-in basic electric circuit kit as teaching aids will also help to reduce the cost, space, time, and energy of the user, regardless the student or the teacher because the development of basic electronic circuit kit is easy to carry and light. Other than that, the generated teaching aids will also help with the student difficulty in recognizing and understanding the types of electrical circuits.

\section{c) Design phase}

After the requirement analysis phase is done, the design phase will then start. In this third phase, the basic electric circuit kit will be developed based on the appropriate design to enable the product to be created can address the problem faced by the student. Several sketches have been produced, but only one sketch will be chosen as a final design for the product to be developed. For the design of the kit, the researcher had chosen the idea from the problem faced during the practical and theoretical study of electrical topics. The design plays an important role in a project that is going to be developed.

The design produce for this product should be in accordance and suitable with the teaching and facilitating process. The size of the design is also crucial in determining the success of this product towards the process of teaching and facilitating. This is because the product will have many types of electrical circuits that can be viewed more clearly and the demonstration will be successful as the student will focus on the demonstration and is easy to understand. 
Therefore, the size of this development project has been decided to be $30 \mathrm{~cm} \times 39 \mathrm{~cm} \times 6.5 \mathrm{~cm}$ (width $x$ length $x$ height). This design is easy to use and can be seen by all students from various angles. In this product design, various aspects have been taken into consideration in completing the project. There are two aspects that should be focused on by the researcher in the construction of this project where the first one is the physical design of the project in which the construction of the project framework and the second one is the design of the electrical circuit in which the part to be focused is the component connection.

\section{d) Implementation phase}

The implementation phase is the last phase in the process of product development. Through the design phase, the basic electric circuit kit project was successfully developed. The basic electric circuit kit can be used as a facilitator for both students and teachers in studying the types of electrical circuits.

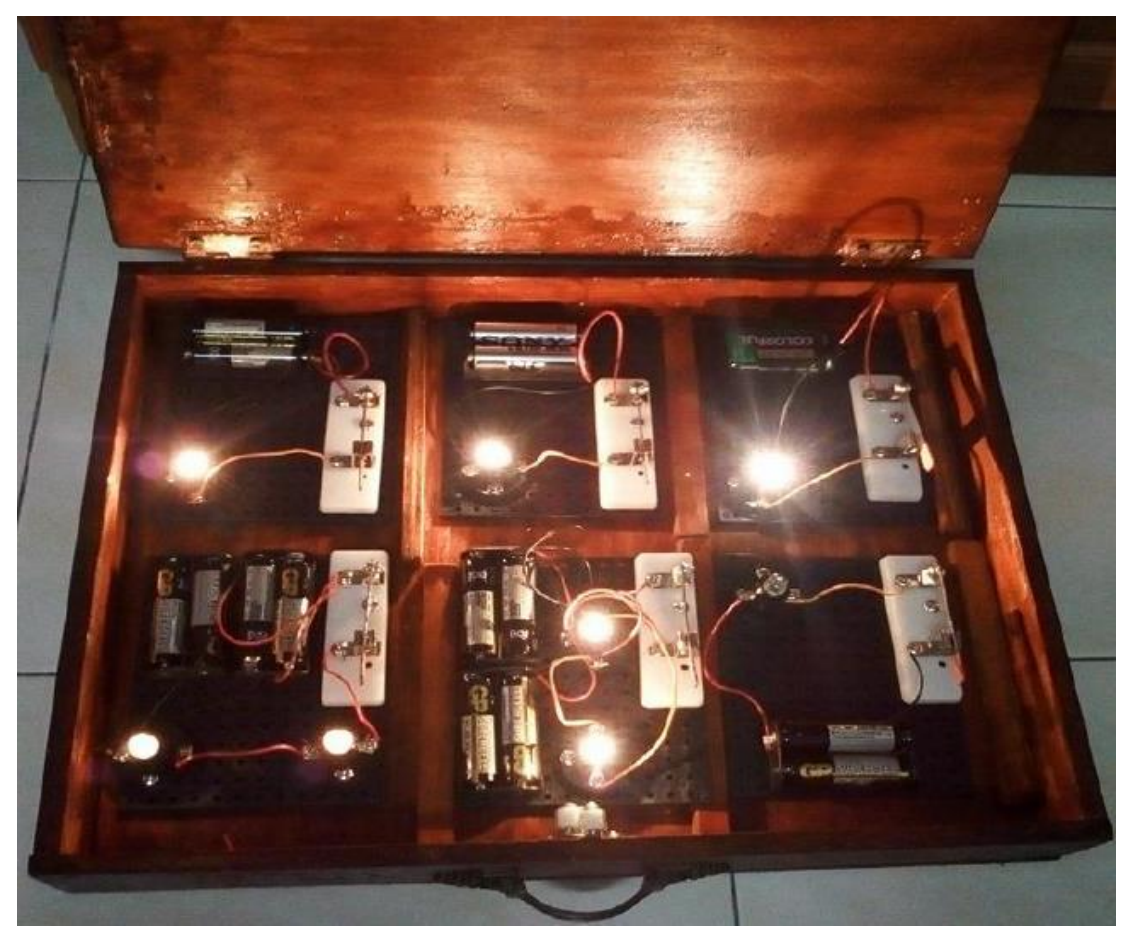

Figure 1: Basic Electrical Circuit Kit

\section{Discussion and Conclusion}

With the development of a basic electric circuit kit as one of the teaching aids for the Design and Technology subject, it will help the student in identifying the types of circuits, thus further help them to translate and described the circuit more easily and accurately. In addition, by using the basic electronic circuit kit as teaching aids, it will help the student to pay their attention and be more focused in the class compared to the process of teaching and facilitating that only used a blackboard and slides. Besides that, the built-in basic electric circuit kit design that has been developed is interesting and can influence the student to continue to learn and attract their interest in learning topics related to electrical circuits. 
Whereas, in the context of suitability to use the product in accordance with the topic of learning, the basic electrical circuit kit is at a good level of suitability as the product is easy to carry and is fit to use either in classrooms or workshops. This is because the product has six different types of circuits housed in a small portable kit. In conclusion, the use of basic electric circuit kit as teaching aids in the process of teaching and facilitating can help in achieving the learning objectives more effectively. This tool not only facilitate the process of understanding, but raises the student motivation to do something which is in accordance with See Kin Hai (2008) in his study, "teaching aids are used to enhance learning, promote higher order thinking skills and problem-solving skills.

\section{Acknowledgement}

This research is under the University Research Grant (Code Project: 2018-0062-107-01), Research Center of Management and Innovation, Sultan Idris Education University.

\section{Correspondent Author}

Zaliza Hanapi

Fakulti Teknikal dan Vokasional Universiti Pendidikan Sultan Idris

Email: zaliza.hanapi@ftv.upsi.edu.my

\section{References}

Abdul Rahim, H., \& Hayazi, M. Y. (2010). Penggunaan Alat Bantu Mengajar (ABM) Di Kalangan Guru-Guru Teknikal Di Sekolah Menengah Teknik Daerah Johor Bahru, Johor. Universiti Teknologi Malaysia, 1-8.

http://eprints.utm.my/id/eprint/10879/1/Penggunaan_Alat_Bantu_Mengajar.pdf

Abdullah, N. S., Abidin, R. Z., \& Mohamad, S/. (2008). Kesan Penggunaan Kit Pengajaran Bersepadu Magnetik-PLC Terhadap Kefahaman Konsep Asas Kawalan Magnet Dan PLC. Batu Pahat, UTHM.

Abu Hassan, N. (2004). Kebolehgunaan Kit Pengajaran Dan Pembelajaran Bagi Meningkatkan Prestasi Pelajar : Satu Tinjauan Di KUITTHO. Master Thesis, Kolej Universiti Teknologi Tun Hussein Onn.

Madar, A. R. S. S. (2008). Pembangunan 'Digital Elektronik Kit' : Satu Pendekatan Visual Dalam Aplikasi ABBM. Batu Pahat, Fakulti Pendidikan Teknikal, Universiti Tun Hussein Onn.

Dahaman, A. (2011). Penyelidikan Pendidikan Tinjauan Literature / Sorotan Kajian.

Zakaria, N. (2016). Model Kit Kaedah 4M Kod Warna Perintang 4 Jalur Sebagai ABBM, Universiti Tun Hussein Onn, Johor.

Hassan, R. (2017). Pembangunan Resistor Educational Kit With Component Tester Sebagai Alat Bantuan Pengajaran Dan Pembelajaran (ABBM). Jabatan Kejuruteraan Elektrik (JKE), Politeknik Sultan Salahuddin Abdul Aziz Shah (PSA).

Ramzi, W. A. W. Y. (2014). Kajian Keberkesanan Kit Amali Litar Asas Elektronik Pelajar SKS Kolej Komuniti Masjid Tanah. Kolej Komuniti Masjid Tanah, Melaka Malaysia 